1983-09-01

\title{
Current Trends in the Planning and Development of Northern European Collections
}

Richard Hacken

hacken@byu.edu

Follow this and additional works at: https://scholarsarchive.byu.edu/facpub

Part of the Collection Development and Management Commons, and the European Languages and Societies Commons

\section{Original Publication Citation}

Collection Management, Vol. 5(3/4), Fall/Winter 1983, pp. 69-87. Copyright Haworth Press, Inc.

\section{BYU ScholarsArchive Citation}

Hacken, Richard, "Current Trends in the Planning and Development of Northern European Collections" (1983). Faculty Publications. 1210.

https://scholarsarchive.byu.edu/facpub/1210

This Peer-Reviewed Article is brought to you for free and open access by BYU ScholarsArchive. It has been accepted for inclusion in Faculty Publications by an authorized administrator of BYU ScholarsArchive. For more information, please contact ellen_amatangelo@byu.edu. 


\title{
Current Trends \\ in the Planning and Development of Northern European Collections
}

\author{
Richard D. Hacken
}

\section{REFERENCES}

American Library Directemy. 33rol. ad. Neu York: R. R. Bowker. 1980

Equity." National Association of College and Bundecse by the Lniversities: A Call for

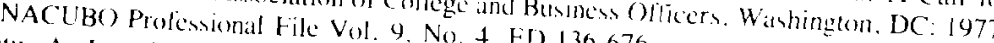
Coutu, A. J. and Jones, F. Willon "Review and 136676

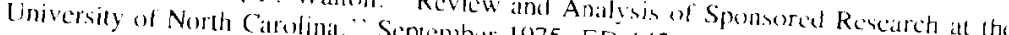
Hernon. Peter. Use of Gorerume Peptember 1975. FD 142108

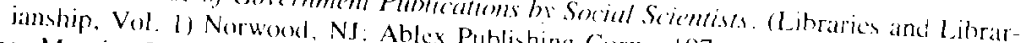
Line, Maurice B. "The Ability. of ablex Publishing Corp., 197

searchers. "Iormal of Librartanship, 5:37-51. Office of Mantagement and Budget Pripiphe 51

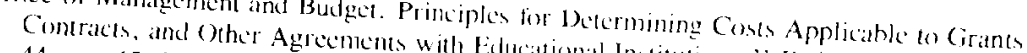
44, no. 45. March 6. 1979, pp. 12369-12380. Institutions." Federal Register, vol Orburn. Chatks. B. Aculemic Re $12.369-12380$

America. (Now Dircotions in Libratand libraty Resources: Changing Resources in Press, 1979.

Universily Press, 1979. The Repent of the Nentional Enduing. Bathinore: John Hophin

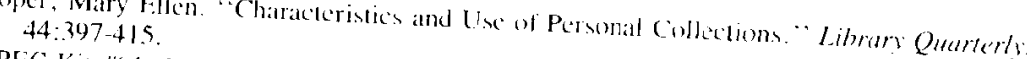

SPEC Kil t6t.

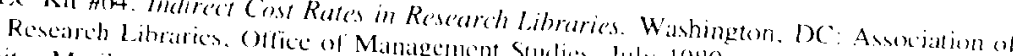
White, Marilyn D). "The (ommuniculane Behaties, July 1980.

Phases." Library Quarterts. 45:337-353

\begin{abstract}
Current planning and development of collections in the social sciences and humanities for German-speaking Europe, the Netherlands and Scandinavia reflect the changing needs of research, strict budgetary limits, the prevailing publishing market in those countries, and certain innovations in library automation. Librarians responsible for supporting an area study of Northern Europe may shape the trends to their advantage by careful policy planning, by informed financial choices, by the use of data bases and resource sharing. by privately-nurtured channels of acquisition and support and by a continuing self-education program that might include participation in the activitics of the CES and WESS.
\end{abstract}

If Franz Kafka were alive and managing a Northern European collection in an American research library today. it is not entirely inconceivable that he might pen an ultra-short story such as the following:

It was early in the fiscal year, the stacks semi-bare and deserted, I was on my way to review collection development policy statements. As I compared local research needs with actual holdings and measured the good will of conspectus drafting against the current state of resource sharing, I realized it was much later than I had thought and that I had to hurry; the shock of this discovery made me feel uncertain of the way, I

Richard D. Hacken. Ph.D., is European Studies Bibliographer, Harold B. Lee Library, Brigham Young University, Provo. Utah 84602

Collection Management, Vol. 5(3/4), Fall/Winter 1983

1984 by The Haworth Press, Ine. All rights reserved. 
wasn't very well acquainted with the new budgetary realities as yet (though I had just paid 200 Marks for a modestly-sized paperback monograph); fortunately, there was a library administrator at hand, I ran to him and breathlessly asked him the way. He smiled and said: "You asking me the way?", "Yes," I said, "since I can't find it myself." "Give it up! Give it up!" said he, and turned with a sudden jerk, like someone who wants to be alone with his laughter. ${ }^{1}$

Indeed, a number of recent factors modifying the collection of materials from German-speaking Europe, the Netherlands and Scandinavia could justify such Kafkaesque pessimism. Excluding the German Democratic Republic, these very lands now seem to be charging more per given library item than any other group of countries on earth. At the same time, U.S. libraries have passed beyond the affluent post-Sputnik boom into a recession that could be more indicative of the once and future poverty of acquisitions funding. Against this background, college students are staying away from foreign language study in droves, and are shifting more and more from the humanities to the social sciences and hard sciences, which results in diminishing use of books and serials in the vernacular. Thus, library administrators find it increasingly difficult to justify levels of funding once allotted to Northern Europe, where the high cost of available materials must be juxtaposed against a relatively low rate of use. In addition, other long-neglected area studies now compete for funds. (At times, it may be implied that many decades of library support for European studies must surely have resulted by now in a complete bibliographic apparatus and sufficient research materials.) On top of all this, the computer revolution has just been declared, in effect causing many book budgets-not just those for Northern Europe-- to help underwrite an electronic promised land upon which we have just set foot. At the nub, the researcher into Northern European humanitics or social seienecs has changing needs that cannot be filled with the acquisitions-or even the collection policies - of yesteryear.

If the state of affairs deseribed above could justify pessinism, it also suggests a survival mode to those inclined to utilize such trends to their advantage, if possible, rather than to capitulate.

The following trends in (I) researeh needs, (II) financial responsiveness, (III) publishing realities, and (IV) technological advances will be reviewed in the context of the German-, Dutch-, and Scandi- navian-speaking countries, bearing in mind that many of these comments may apply to other parts of Europe or the world in some measure.

\section{TRENDS IN RESEARCH}

One of the emerging needs in social science research ${ }^{2}$ involves greater access to quantitative data. The desired reconstruction of demographic and economic aggregates may require a collection manager to go well beyond Statistisches Jahrbuch fiir die Bundesrepublik Deutschland, Jaarcifers voor Nederland. etc., and into more ephemeral documentation covering economic policies, social issues, or public opinion. Still, the budget picture does call for close communication with local researchers, to guarantee the ordering of relevant data that will be used and usable. In certain instances, the social scientist on location will be a producer-rather than consumer-of unpublished quantitative data that might be appropriate for inclusion in the collection and for access to the library community at large.

Another research trend in the social seiences involves what Peter Gourevitch has called the "collapse of boundaries." Many research problems now tend to be probiem-related rather than discipline-oriented; as a result, Europeanists" studies broaden to statesociety relations and to "political cconomy," encompassing virtually everything from economic policy to political leadership. The boundaries between the humanities and the social sciences have definitely not "collapsed," though research is done into literary sociology and into society"s "reception" of various forms of art. In any case, there are no particular problems involved in procuring present books and serials with an interdisciplinary approach, since they are still closely aligned to traditional disciplines (and publishers).

Within the disciplines themselves, certain forces of change are at work; one clear indication of these is the allocation by disciplines of eleven fellowships awarded by the Council for European Studies in the academic year 1982-83: six in history, three in anthropology and only two in political science. ${ }^{4}$ Ten years earlier, the discipline of political science had been firmly in control of the European scene, but political studies gradually began to take on the onus of trendiness and to be replaced by the aforementioned "political economy," by social history, and by women's issues. One highly interesting and 
perhaps unexpected twist in the above figures is the respectable showing of anthropology; current scholarly concerns find field research on the human population of an industrialized Swedish town just as valid as that of an island in Polynesia, not to mention more amenable to North American comparisons.

In Germanic studies from the Middle Ages onward, social and economic history are generally stimulating greater interest and taking up the slack left by the political history. Medieval archaeology in particular is an area where the library collector can support a current research emphasis. 5

Even after consultation with active research faculty, we must rely on "outguessing history" to some extent, which can be seen as informed gambling to inprove the odds of acquiring valuable data Agnes Peterson of Stanford's Hoover Institution sees the cooperative program of microfilming "Captured German Documents" and of providing guides for it-as a major example of outguessing history in the recent past. ${ }^{6}$

A related problematic area for the Germanic literature collection is the challenge of outguessing literary fame on the contemporary scene. One costly solution-probably untenable in many budgetary schemes today-is to order a fairly comprehensive coverage of authors (by blanket order or otherwise) to assure holdings of future literary standouts. Another, more economical solution might be to obtain representative holdings of the obvious and probable authors of research interest or curricular use, and to maintain a holding pattern for others to prove themsclves. A fairly recent example of this plan's practicality was the awarding of the Nobel Prize to the German-language author Elias Canetti, which both created a greater library demand for works by and about him and a greater supply of them by the publishing world.

A development in the humanities has been toward a quantification of words; the literary concordance has taken on new importance in the criticism of German-language authors. (Literary scholarship in the Netherlands and Scandinavia has not yet reached this stage; even for German literature, an author's historical-critical edition must be available before a reliable concordance can be produced.) Not surprisingly, this is one area where automation proves to be a boon: computer-generated concordances are now the rule. At my own institution, a "Kurzweil Reading Machine"' has been adapted to input German text directly from the page to the computer memory. Still, a concordance is useless to a library where either the author is not ac- tively read or where word quantification rescillch .uml moleren w absent. Again, it is the patron-researcher who must supply the tor

To give a further idea of where library suppoul al (bormmin

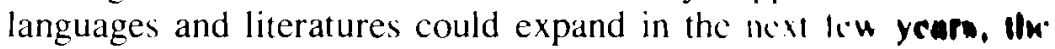
following excerpts from a list of research tool necds mulluked an mini priorities by North American Germanists:

1. A comprehensive bibliographical listing of library holdong "II German-American literary relations.

2. A bibliography of Forschungsberichte.

3. A dictionary of Early High German (as a prerequisite for onhe' specialized reference works).

4. An iconographic/topological dictionary of metaphoric tems. emblems, etc. (possibly combined with a theme and motif in dex of medieval literature)

5. Verfasserlexika for the 16th through 20 th centuries.

6. A text inventory of German manuscripts in North American libraries and archives (not just of literature!).

7. An updated, modern German etymological dictionary.

And the list goes on. ${ }^{7}$

In answering evolving rescarch needs, we will need not only to remain informed about the availability and desirability of new types of materials, but, perhaps more importantly, to work toward providing bibliographic information at the national and local levels and toward guarantecing lucid and logical access points in the patrons' catalog for itcms already in the collection.

As today"s Northern European Studies scholars stare down the barrel of the same fiscal firearms that have wounded the bookcollecting effort, they too will find themselves less often in a position to visit the archives of Uppsala, Wolfentütel or The Hague, and more often dependent on our best indices, best holdings and best consortium efforts for documentation and document delivery.

\section{FISCAL TRENDS}

Undoubtedly the single most informative article on the new fiscal realities involved in ordering books and periodicals from Europe is that of Erwin K. Welsch: "European Collection Development in American Libraries: Problems and Prospects. "' Welsch places par- 
ticular stress on the impact of Euro-inflation upon American collect ing patterns and techniques. One of the first areas of adjustment he describes is the blanket order program, which has suffered cuts and cancellations from many institutions in response to increasing material costs and decreasing book funds. Where blanket order programs still do exist, they have been refined of necessity into much more strictly defined profiles in order to avoid the receipt of materials of questionable use. This in turn, however, only intensifies "mirror collecting." As a number of institutions submit nearidentical profiles for European discipline areas at near-equal levels of collecting intensity, it is natural that they will receive nearly the same titles. This means they will also lack the same titles, often in local history, minor authors, ethnic minority studies, specialized data, etc. As cooperation within-and between-consortia becones more fully realized and as conspectus planning reaches its potential. it secms clear that research libraries will be obligated to collect their own particular specialties more comprehensively, even at the expense of more "central" or "najor" monographs or serials. Cooperative acquisitions, in the case of Northern Europe's inflated book prices, seem to make very good sense indeed.

It is no mere coincidence that at the very time libraries are foreed to be nore selective in their buying, the publishers of Europe are themselves being more selective in the books they produce. This is not necessarily to our benefit, however. since the selectivity increasingly manifests itself in reduced press runs and limited distribution as much as in editorial weeding of less desirable works. For the foresceable future, a factor to watch is accelerating rapidity of materials going out of print in the Germanic countries previously noted for long stock shelf-lives. The means of adjustment may be a limited approval plan, a reliance on advance publication information, or quicker response to new offers. We have cause for optimism, however, in that the state of national bibliographies for Northern and Central Europe is marked with relative speed and reliability when compared to that of the Southern region.

A few brief examples from Welsch's tindings should suffice to illustrate the inflationary trends of Northern Europe (which also reflect higher taxes, postage and service fees). The paperback twenty-volume set of Bertolt Brecht's works rose in cust from $\$ 30.00$ in 1967 to $\$ 100.00$ in 1980; those of Hermann Hesse in twelve volumes from $\$ 22.00$ in 1970 to $\$ 66.00$ in 1980 . An edition of Ibsen's play Gengangere cost $\$ 1.65$ in 1970 and $\$ 8.55$ in 1980 . A random sample taken from invoices at the University of Wiscums!1 showed a one-year increase in the cost of West Gemlan hom, 1m,11 1979 to 1980 at 23 percent and of Danish books at 45 percint. 1.11 outstripping the inflation indices for other types of consumler fourls The serials picture projects a similar image: among the more morken increases from 1967 to 1980 was Bonniers litterära magasin, whith nevertheless rose from $\$ 11.26$ to $\$ 19.35$. Among the most asturund ing rises on a percentage basis during the same period was the laist German Zeitschrift fü Geschichtswissenschafien which skyrocketed from $\$ 7.00$ to $\$ 52.43$. The West Germans didn't let any grass grow under their accountants either, as the ubiquitous Spiegel went soaring from $\$ 25.30$ to $\$ 208.88$. One literary journal, Akzente, actually upped its subscription price by 96 percent in the twelve months from 1979 to 1980. The worst news, pcrhaps, is that prices have been expanding at ever higher rates since about 1977, and show no inclination to slacken. "The dollar's strong rebound at the time of this writing does not nullify the inflationary spiral, and indeed favors purchases in the Italian lira or French franc over those in other European currencies, a tendency that seems likely to continue.

An economic "recovery," unless pronounced and long-lasting, can only stabilize the present climate, since publishers on the one hand and library administrators on the other--having been "burnt" once-will not be apt to foster accelerated growth in Northern European collections by deviating from the status quo.

Antiquarian books are subject to the same harsh facts of economic life. of course, as new releases. The budget crisis means that antiquarian prices in Northern Europe are up while the number of libraries able to purchase out-of-print matcrials aggressively is down." Even assuming that resource sharing becomes wide-spread and efficient, therc are certain types of retrospective purchases that belong permanently accessible in a local collection. Those libraries that have, through the years, obtained relevant works shortly after publication may count themselves fortunate, since they have enjoyed a double saving: they have purchased journal runs and needed monographs at former retail rates and are spared the search and added expense now. Other libraries-my own included-have been obliged in past years to augment the research potential of German, Dutch and Scandinavian materials retrospectively at great cost, not only through individual titles, but through block antiquarian purchases of entire subject areas, e.g., of the Northern Renaissanee, Austrian social history, or writings of the Nazi era. Today, such op- 
portunities are becoming rarer, both on the part of supply and demand. The costly procedure of acquiring out-of-print materials teaches a sober lesson about obtaining clearly needed items as they are published, rather than at the inevitable mark-up later.

While second-hand books may often be less expensive than reprints in the United States, the same has not held true for Europe Until now, the reprint has been a viable alternative to the antiquarian book, especially in the German-speaking countries-to the extent the desired title has been available. But that reprint market today is in the word of Knut Dorn, "dead;" in its retrenchment throes, it is printing smaller runs of ever fewer titles. ${ }^{12}$

The microform industry seems a safer bet from the marketing angle: a reprint has to sell from 80 to 120 copies to break even in its publishing venture, whereas a microform can break even and begin accruing profits after only 15 to 40 copies have been sold. Thus, it is not surprising to find many of the latest reference offerings (Deutsches Biographisches Archiv, catalogues of the Royal Library of Copenhagen, The Austrian National Library, and others) as well as specialized collections (Marburger Index; German-Jewish Periodicals, 1845-1938; Bibliothek der deutschen Sprache) appear-
ing in microform.

And finally, what of resource sharing as an answer to collection gaps? To what degree, for instance, can a collection manager save local funds and still meet research needs by relying on the Center for Research Libraries (CRL) for most foreign dissertations? Will consortia become effectively more than cataloging co-ops and interlibrary loan cliques? Will the RLG conspectus, in its proposed expansion within the ARL, become a new Farmington Plan? ${ }^{13}$ If questions such as these can be positively resolved, the national collection of resources on Northern Europe will be available for ready searching, and future collection planning may be coordinated to the benefit of all.

As unit prices rise and budgets tighten, the number of items an individual library can receive from Northern Europe exponentially diminishes. It appears unlikely under such circumstances, generally speaking, that gift and exchange acquisitions of sufficient quality and quantity will flow in to close the gap. Although this dilemma may eventually work toward relieving other library pressures, e.g. catalog backlogs and shelving congestion (what small solace!), the depth of the scholarly European collection at the local level must suffer and is suffering. The inescapable conclusion? Information sharing, acquisition sharing and resource sharing have stepped beyond the bounds of nice ideas and into the realm of raw necessity. ${ }^{14}$

\section{PUBLISHING TRENDS}

It would be self-flattery to assume that purchases from this side of the Atlantic make a measurable impact on book publishers' deeisions in Northern Europe. Although Dutch and Scandinavian publishers in particular do court the English-language market, they are almost totally dependent on national-rather than internationalreadership when it comes to domestic works in the vernacular. Even the West German export market only saw 7.2 percent of its book production and 3.4 percent of its journals shipped to the U.S. in 1980, figures that have been steadily declining since 1972. ${ }^{15}$ Thus, publishing trends in the region are naturally tied most closely to the home market, and that home market has been as beleaguered as our own (especially for scholarly publications).

\section{Federal Republic of Germany ${ }^{16}$}

The global recession has been experienced variously from country to country, but even the land of the "economic miracle" has been forced to tighten its belt several notches. In the academic and research library communities of the Federal Republic, for instance, acquisition budget cuts of between 30 percent and 70 percent are the rule, and other service aspects have suffered. ${ }^{17}$ The change has been somewhat sudden, but it took the West German publishers over two years to adjust to the new squeeze. Despite the general economic downturn from 1978 on, the official figures released by the Börsenverein des deutschen Buchhandels (The West German Book Trade Association) did not show a reduction in book production until 1981, when a drop of 11.8 percent was noted over the previous year. From 1980 to 1981, German book trade insolvencies increased by 35 percent. The most severe reductions were in scholarly publishing, where Otto Harrassowitz statistics estimate a decrease in production of 25 percent between 1978 and 1981. Belles lettres and non-fiction-which have a market share outside the dccimated German research library demand-have not been undercut as badly, and should maintain a wide range of coverage.

Titles in specialized fields are being printed in smaller runs of 250 
or 300 copies instead of the 600 to 800 copies of earlier years. Traditional in-print availability from such scholarly publishers as de Gruyter, Winter, Vandenhoeck \& Ruprecht, and others will shorten from decades to as little as two to five years. Once a work is out of print, a reprinting is economically risky without a substantially high number of firm orders.

The decline in scholarly monographs means that more manuscripts-even highly relevant ones-are being printed through noncommercial avenues and are being distributed by alternative means. Hence, the Reihe $B$ of the Deutsche Biblographie has become a tool of greater value to librarians collecting from German-speaking lands. The recent broader organization of author-subsidized dissertation publishing (above all by Lang Verlag) represents another change on the publishing scene, one that should be watched to see if it will escape the stigma of vanity publishing and maintain high scholastic standards.

A further reaction to the market has been to eliminate some of the more costly publishing projects, especially Festschriften and multivolume printed catalogues. It is debatable, for example, whether Klaus Saur could afford under the present conditions to undertake his valuable Gesamtveraciclmis des deutschsprachigen Schriftums, $1700-1910$ and $1911-1965$ in printed form.

The moribund state of German reprinting has cleared the path for microform publishing. We can expect to see larger projects appearing in this form in the years ahead. ${ }^{18}$

Though reprints are disappearing, curiously, facsimile printing of precious manuscripts and early book production continues undiminished, which may be due to wealthy private collectors who make up an important segment of the clientele.

\section{German Democratic Republic ${ }^{19}$}

The economic plight has not bypassed the countries of the Comecon, and in fact the case of the GDR exhibits the additional burdens of a planned economy and centralized political control. Not only is book production tied to financial factors, as in the West, it is also tied to the social and political climate. Approval of a book for printing or for a second printing may be dependent as much on its utility to the long-range goals of the socialist state as to its expected "demand." Allocation of paper quotas to publishers is one form of control, although paper supply is also a genuine problem. As an example of official censure, Christa Wolf's controversial novel Nach- denken über Christa T. quickly sold out in 1969, but was not made available in a second printing for another four years. Since 1979, heavy penalties for authors who negotiate with Western publishers without official approval have discouraged that alternative for publication of state-rejected manuscripts. In the same time period, to all indications, the number of novels published has dropped sharply.

The overall output of titles for the past decade by East German publishers has remained at approxinately 10 percent of the West German production, although when the Federal Republic dropped from 67,176 to 59,168 titles between 1980 and 1981, the Democratic Republic showed a slight rise, from 6, I09 to 6,180. It does seem likely that the number of titles produced in the GDR will hold steady or show decreases for the foresceable future.

East German publishing houses cater to strictly assigned subject realms. Their various outputs are further partitioned by governmental directive into differing ratios of domestic and export consumption, a practice that might help to explain the greater difficulty in obtaining one title in print over another. All exports are centralized through an agency that operates both Buch Export and the Zentralantiquariat.

The dual pricing structure remains unchanged, with a higher price set for export of most titles to the West; even so, the prices still represent by and large some of the best bargains in the Germanspeaking world.

When a book goes out of print in the GDR-as most do very quickly - this is due not only to the limited size of press runs, but also to the voracious domestic appetite for reading matter. As with other commodities, the idea is to buy before the local supply is cxhausted or channeled into the export stocks. For the North American librarian, this points to a need for consistent and timely selection procedures, either directly through pre-publication announcements of Nova, or through an approval plan with a West German dealer who has established contacts with Buch Export. Standing orders are a wise precaution for series which are important to a collection.

Even a conscientious collector will find certain East Gernan titles quite simply unavailable. Government and institutional publications, for instance, are not generally exported. Another restriction can be blamed on legal injunctions made by certain West German publishing-house owners who re-established themselves in the Federal Republic after World War II and now object to their names still being used by companies in the East. Thus, titles of the Reclam and 
Brockhaus Verlag Leipzig may not be sold in the West. Other companies, such as Teubner, Niemeyer, Insel, and most recently Bibliographisches Institut Mannheim-formerly of Leipzig-have made more liberal arrangements to allow their namesakes' books into the West.

Beyond that, a linitation that appears likely to continue and intensify is that of the inner-German licensing arrangement. Under the varying terms of such agreements, the rights to a given author or work are shared-not always equally-by one publisher in the West and one in the East. The main point here is that an East German edition-even if substantially different in content-may not be exported to the West. This can present an obstacle even for identical editions if the West German, Swiss or Austrian publisher sits on the rights for a long period of time after an East German printing has already appeared. One way out of the licensing cul-de-sac for certain titles may be to obtain them through countries not specifically excluded in the contractual restrictions, e.g., through Holland or, in some instances, by direct sales to the U.S. or Canada.

\section{Austria}

The economic base and trends of Austria appear to be so congruent with those of the Federal Republic of Germany that the same publishing pattern can be safely assumed for the next few years. The downturn in Austrian publishing occurred in the same 1981 period as that of the FRG, almost exactly mirroring the West German reduction of new titles at 11.9 percent. One difference, however, is that the Austrian publishers had been expanding titles at a much slower rate from 1976 to 1980 (14 percent in that time period versus 43 percent for the FRG);20 consequently, they should be able to regain equilibrium somewhat sooner. Still, the siege mentality prevails, deepened by the exemplary and resounding collapse of the highly-regarded Molden Verlag. Higher selectivity in titles to be offered and lower press runs-above all in scholarly publications-will be the new rule here as well.

\section{Switzerland}

The Swiss Frank and the Swiss bank continue to offer an oasis of economic stability in Europe, such that Switzerland should be able to maintain or even upgrade its book production. This is not to say that the gnomes of Zurich did not have to adjust to the globial ters sion. The fact is that they were able to do so a full year before "lli'/t booktrade neighbors. From 1979 to 1980, as the West (icrmitll publishers were still expanding their titles by 8 percent and Austrlit was following suit at 6.6 percent-against all economic indicitturs and logic-the Swiss publishers had already made a compensittory adjustment downwards of over 27 percent. Biting the bullet at the right time has evidently paid off, as the Swiss publishing scene ap pears to have recovered and stabilized. Still, the number of annual titles is down from the figures of five years ago, and smart publishers in the Helvetian confederation are not about to overextend themselves by allowing their offerings or the size of their editions to grow too rapidly.

\section{The Netherlands ${ }^{21}$}

Another country with stable publishing credentials, considering its small domestic narket, is the Netherlands. The market showed only about 4.4 percent fewer titles published in 1982 than in the previous year (from 13,939 to 13,324). The specific segment of English-language publishing was actually up by a margin of 8 percent. $^{22}$ This bill of good health, particularly within academic publishing, can be ascribed in part to the fact that two groups of publishers, Elsevier and Kluwer, control about 70 percent of the scholarly output. These giants are not as easily affected by recessionary times. They are internationally diversified as well: Elsevier publishes under the imprints of American Elsevier and North Holland, for example, and owns the New York firm of E. P. Dutton. Also, the rate of Dutch inflation in 1982 was only 6 percent, and is projected at 5 percent for 1983; price increases should moderate somewhat. As in the German-speaking countries, though, price increases will often exceed inflation rates, a result in part of fewer copies per title.

A trend worth noting for those research libraries collecting materials from Friesland is the recent renaissance of Frisianlanguage publishing. If some years back Frisian books were an unprofitable anomaly, they are today being both printed and sold in greater numbers. One reason behind this has been the reintroduction of Frisian language instruction in the schools since 1974; also, greater sales promotion and government subsidies have contributed to the strengthening booktrade. The Netherlands government has in- 
creased its annual subsidies for the preservation of Frisian from 100,000 guilders 10 years ago to a present level approaching one million guilders, a large segment of which goes into book production. ${ }^{23}$

\section{Scandinavia in General}

Publishing crises are nothing new for the Scandinavian booktrade, with its limited and linguistially-partitioned readerships that are well-educated and attracted to foreign-language publications. Booktrading has always been an inflationary and risky business there, even without the aftermath of a recession. Pcrhaps for those very reasons, Nordic publishers have been obliged for at least the past two decades to calculate the number of new titles and the size of editions very carefully - not relying on income from a world market except for English-language printings. Despite higher prices. though, careful inventorying and governmental subsidics have allowed for growth. From 1966 to 1980, overall numbers of new titles grew in Sweden by 13 percent, in Denmark by 67 percent, and in Norway by 74 percent. ${ }^{24}$

\section{Denmark}

Of these three countries, Denmark appears to have fared the best in the past decade. Between 1976 and 1980, Denmark was the only one of the three to show a net increase in new titles, from 6,783 to 9,256 . Since 1980-and even including a slight decline in 1979-there has been an adjustment downward, but we can assume that the careful pattern of planning to date should forestall any precipitous drops in production.

One factor for American libraries to keep in mind when ordering Danish books is that the value added tax (VAT) of over 22 percent is included in the listed catalog price, and should be deducted for import to this country. The savings are significant enough to merit watching in invoices from Danish dealers or jobbers from a third country. ${ }^{25}$

In Denmark, as with all of Scandinavia, books can go out-of-print quickly; those titles significant for the collection should be decided upon and acquired without delay.

\section{Norway}

In the period from 1976 to 1977 , Norwegian nicw Illlen plum meted by 15.7 percent (from 5,722 to 4.823), and wete vill unalis.

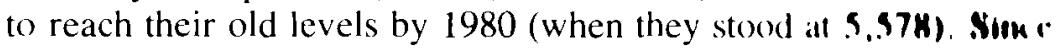
this drop in book production antedates the latest recission, furtin's trends in Norwegian publishing will be important to walch.

In the 1960's the government of Norway studicd and imple mented ways of preserving the native fiction, which had becomse lun expensive for the citizens and too unprofitable to the publishers." Through a purchase agreement, each new title of contemporary Norwegian literature is distributed automatically io regiomul libraries at state expense, and larger press runs are possible at lower cost. In addition to an agreed purchase of 1,200 copies, the govern ment assists in paying author royalties, grants stipends $10 \mathrm{ncw}$ authors, and exempts all books from the VAT. The Amcrican library benefits not only from the absence of the VAT, but from the lower prices nade possible by the purchase agreement (estimatted at 37.5 percent for an average book of poetry. $)^{27}$

A consequence of the Norwegian purchase agreement has been a greater proliferation of fiction and poetry, even when other titles. c.g., in the social sciences, are declining. Publishers may be encouraged to market poetry collections of dubious merit with an in sured profit. Thus, the collector's task to find literature of true sig nificance is rendered more difficult.

\section{Sweden}

Swedish book production, after a two-year high in 1974-75 of over 9,000 titles, dropped to a level of 5,256 titles by 1978 , and then climbed again to 7,598 in 1980. The long-range figures suggest a somewhat more volatile book market in Sweden than elsewhere in Scandinavia, and indeed despite the absence of more recent statistics there are indications that recession has arrived there. A comparison of "Fact Sheets on Sweden: The Swedish Book Market" printed by the Swedish lnstitute in May of 1980 with that printed in Octoher of 1982, shows 275 professional booksellers in Sweden in the former. 255 in the latter-an indication that the book business has been eating its own. A governmentally-funded program through $A B$ Seelig \& Co. to maintain complimentary stocks for bookshops hald 
appeared in the 1980 fact sheet, but was conspicuously absent in the 1982 follow-up. The Swedish book market should be followed with a cautious eye during the next while.

Nevertheless, Swedish literary subsidies-following the lead of the Norwegian purchase agreement-have changed that realm of publishing since 1975. Unlike the Norwegian plan, the Swedish agreement calls for a more selective program; as a quality check, a minimum of 24 libraries nust choose a given title before it becomes eligible for subsidies. Also, a chosen book circulates to bookstores in outlying areas as well as to libraries, ensuring distribution in frozen-but-not-forgotten regions of the north. ${ }^{28}$ Since spring of 1983, publishers have virtually ceased publishing the classics of Swedish literature in paperback. Whatever the reason, it makes these works less accessible to students (if not libraries), and could eventually alter the purchase agreement.

The effect of the Swedish plan on American collecting should be similar to that of the Norwegian: lower increases in prices for hardback fiction. The VAT, as discussed in Danish list prices, applies to Swedish orders as well.

\section{TRENDS IN AUTOMATION}

In counterpoint to the increasing cost of printed matter in a time of great informational needs, the silicon chip has been decreasing in cost while expanding its horizons of potential use. The technologies available in America today that hold promise for European collec tion management include management information systems, automated acquisitions systens, and online networks. ${ }^{29}$ Especially attractive at the local level are integrated systems that promise to do the following: supply data on user profiles; analyze costs; break down holdings by subject, language, country, call number or publisher; continually update an online catalog, generate serial claims, trace a particular title to its point of collection decision, acquisition, cataloging or circulation-all of this and more through a handy number of user-friendly access points, of course.

Perhaps it is not a misplaced dream to suppose that one day soon the collector may key into a private desk terminal (in the library or at home) to search the week's offerings in the B-lijst of the Nederlands Bibliografie. supplied by the Nederlands Bibliografisch Centrum $^{30}$ and beamed by satellite to an online vendor of national bibliographies located in the upper Midwest. Spotting a title that appears to fill a need in Frisian social history (as revealed by a peek into the Dutch history local priorities mode of the memory), the collector then qualifies the title for purchase by electronically searching the local holdings and by checking the online RLG/ARL conspectus and network holdings to reaffirm that this local specialization will become a regionally unique resource as well. This accomplished, the collector next chooses between a bound print copy or electronic document delivery before pushing the "order" button. During this process, the acquisitions, cataloging, serial and circulation modes have been reflecting each nuance of the procedure in order to assure a completely integrated record. The budget mode allows the transaction to occur, then dutifully makes a subtraction. In this particular casc, the document is delivered - by fiber optic cable through a U.S. online depot in Silicon Valley-to Professor Van Hoekenrijk's own home terminal, where by pre-arrangement a blinking orange light recalls him from a snack of herring.

The scenario above may not be as remote as it seems: the online RLG conspectus is already a fact, as are first-generation integrated systems. In 1980, Euronet DIANE (Direct Information Access Network for Europe) went online with bibliographic databases which, although prohibitively expensive for transmission to North America at present, can only become more sophisticated and affordable with further developments in technology and telecommunications. ${ }^{31}$ As inputting processes improve, such databases can form the embryo of an electronic publishing network that might prove profitable by the end of this century or before.

Until that utopian age, the collector of knowledge from Northern Europe can make careful choices within the limits now set and can prepare for a changing information environment by interfacing with the handwriting on the wall.

In sum, a time of fiscal retreat is not a time for burning bridges, but for rigging new ones. It is a time for efficient communication with research patrons, for usable policy statements and conspectus plans that intertwine and maximize local, regional and national re sources on Northern Europe. It is a time for steady relations with chosen European bookdealers that can supply needed items while still in-print, as well as for extra effort in nurturing private chammels of support and acquisition to help close the gap between the needed and the seemingly unobtainable. Above all, it is a time for that quali ty uttered in Goethe's last words (according to tratition): "mohr 
Licht." As collection planners come together for more light in such organizations as the Council for European Studies (CES) and the Western European Specialists Section of the ACRL (WESS), gradually the tasks of collection management and bibliographic consorting will become clear, shared and easier.

\section{NOTES}

1. Adapted from "Give to Un!" in Kafka. The Complete Stories, ed. N. N. Glatzer (New York: Schocken, 1976), p. 456

2. Research trends were drawn from the "Symposium on Wentern European Studies and North American Rescarch Libraries." hold May 8-11, 1983, in Minneapolis (abbreviated hercafter as "Sym. Minn."), an well as from observations and discussions with research colleagues. At the time this paper wats written. the symposium proceedings had not vet been published: they will be at wekentere reference to current frends in the minagement of Northern European collections.

3. At Sym. Minn., May 9. 1983. On the same day. Charlen Osburn spoke on "Forees of Change in Patterns of Academic Rescurch.

4. Figures presented by Glenda Rosenthal. Sym. Minn., May 9. 1983.

5. As reporlcd by Richard Ring. Sym. Minn.. May 10, 1983.

6. Sym. Min.. Mily 10. 1983.

7. For a complete listing of priorities. et. Charles Hoffman. "Survey of German

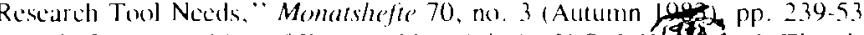

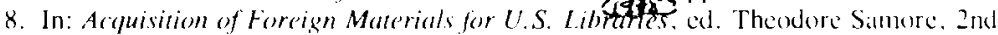
d. (Metuchen, NJ: Scarterow Press, 1982), pp. 12541. A version of Welsch 's arlick alse appears als "Will Amerituan Librarice Continue 10 Have European Boohs?" " Eureperean Simbiex Newstelter 10, no. 4 (March 1981), pp. 1-8

9. Cr. Marion Wilden-Hart. "The Long-Term Elfects of Approval Plans," litrars Resentes and Techmical Services 18 (1970), p. 403

10. Welsch. pp. 128-31

11. Cr. Edi Bjorklund. "Acquisition of Retrospective Materials From Bookidealers: A Librarian s View point," in Samore, pp. 86-91: cf. also Richard W. Dorn and Jane Maddux, "Acquisition of Retrospective Matterial: A View from Harralssou itz," in Samore, pp. 75-79.

12. Knut Dorn, "A Changing Scene German Publishing Moving Inte the 1980" Western Europeren Specialists Section News/etter 6. no. I (January 1983), p. 7: cl. also Eva Kronik s remarks at Sym. Minn., May 9.1983.

13. A question posed by Paul Mosher at Sym. Minn.. May 10, 1983

14. Cr. David H. Stam. "Think Globally-Act Locally. Collection Development and Resource Sharing," Collection Building 5, no. I (Spring 1983), pp. 18-21

15. Knut Dorn. pp. 4, 6.

16. Many of these comments on the publishing pricture in German-speaking Europe paraphrase the article of Knut Dorn named in note above, pp. 4-18, which is an expanded version of a paper presented at the WESS program meeting in Philadelphia on July 12.1982 This is a ne with his permiscion and in the hepe hat his valuable ins hets will reach a broud audience.

17. Blaise Cronin, "Mcanwhile in West Germany. .." Aslit) Proceedings 35. no. 5 (May 1983), p. 213.

18. Among the projects being undertaken on tiche is that of the Zeitschriften-Datenbank. a data base of serial holdings among German libraries that is designed to grow into at Union List of Serials.

19. In addition to Knut Dorn, pp. 5, 14-18, the remarks of Gail Hueting (Sym. Minn. May 10,1983 ) supplied the nucleus of this data on the GDR.
20. Figures for Austria and Switzerland are calculated from LNESCO statistics quoted in Buch and Buchlounde' in Zahl'n 1979. 1980. 1981.

21. M) thanks to Fvert Overeynder fir a copy of his manuscript prosented at Sym. Minn. on Mar 9. 1983: "Trends in Dutch Academic Publishing."

22 "Bockenproductic 1982." Boekblat 150, no. 7 (February 18, 1983), p 30. Figures exclude Flemish editions.

23. Bernard Fridemia. "Some Voter on Book Production in Friesland," wESS News lotter 5. no. 1 (July 1982). pp. 9-10

24. All satistice for Scandinavia are calculated from the UNESCO Statistical Yearbook trom the years 1976 through 1982

25. Welsch. p. 134. WESS Neveleter 3. ne. 2 June 1980) ronernmental subsidies to the booklrade and their impact.

27. Anderson, p. 11. Quoting a publication of Den norske Forleggerforening.

28. Anderson. $\mathrm{p}$. 12

29. Cf. Barbara Magnuson. "College Management: New Technology, New Decision," Wilson Library Bulletin 57. no. 9 (Mily 1983), pp. 736-41.

30. This is not vet as ailable onl ne, ef. Joos Nijsen, "Nederlands Bibliografisch Cen trum: cinklelijk ecen teit." Bockblated 150), no. 15 (April 15, 1983), pp. 18-19.

31. Cf. Franco Mastroddi and Serge Lustac. "Furoned DIANE-A Precursor to Electronic Publiwhing?" " in The Future of the Printed Wort. ed. Phillip Hills (London: F. Pinter. 198(1). pp. 1 11-121: ff. also Ulrich Neveling and (Gernot Wersig. "The Information Scientist of the 198(1) in Lurupe," in Theory and Application of Information Research," ed. Ole Harbo and L cil Kajperge (London: Mansell. 1980). pp. 214-20. 